(online) $=$ ISSN $2285-3642$

ISSN-L = $2285-3642$

Journal of Economic Development, Environment and People

Volume 9, Issue 2, 2020

URL: http://jedep.spiruharet.ro

e-mail: office jedep@spiruharet.ro

\title{
The Effect of Progressive Tax, the Number of Vehicles and Tax Arrears on the Revenue Transfer of Motor Vehicle Title Fees in the South Sumatra Province
}

\author{
Putri Vialeta $^{1}$, Didik Susetyo ${ }^{2}$ and Anna Yulianita ${ }^{3}$ \\ ${ }^{1}$ Sriwijaya University, Palembang, INDONESIA \\ ${ }^{2}$ SriwijayaUniversity, Palembang, INDONESIA \\ ${ }^{3}$ SriwijayaUniversity, Palembang, INDONESIA
}

\begin{abstract}
The purpose of this study is to analyze the effect of progressive taxes, the number of vehicles, and tax arrears on the revenue transfer fees for motorized vehicles in the UPT Regional Revenue Agency of South Sumatra Province. In this writing, the type of data used was panel data. The sample in this study consisted of 16 District / City UPTs between 2017 and 2018. The analysis technique used was Ordinary Least Squared (OLS) using Eviews 8. The estimation results of the regression equation showed that simultaneously progressive taxes, the number of vehicles and arrears had a positive effect and was significant in relation to the acceptance of the transfer of the motor vehicle title fee, as can be seen by the probability value $F$ of $0.000000<0.05(\alpha=5 \%)$. The implementation of a progressive motor vehicle tax has an impact on society, both positive and negative. The positive impact arising from the imposition of a progressive tax on motor vehicles is very influential when it comes to increasing the local revenue. This is useful for financing the routine tasks of local governments for the infrastructure development related to the welfare of the community. However, besides the positive impacts, there are also negative impacts, namely that people are becoming increasingly burdened because the cost of paying the motor vehicle tax is increasing.
\end{abstract}

Keywords: Progressive Tax, Number of Vehicles, Arrears of Motorized Vehicle Tax and BBN - KB

JEL Codes: G38, H2O, H21, H26, H27

How to cite: Vialeta, P., Susetyo,D., \&Yulianita, A. (2020). THE EFFECT OF PROGRESSIVE TAX, NUMBER OF VEHICLES AND TAX ARREARS ON REVENUE TRANSFER OF MOTOR VEHICLE TITLE FEE IN SOUTH SUMATRA PROVINCE. Journal of Economic Development, Environment and people, 9(1). DOI: https://doi.org/10.26458/jedep.v9i2.656

\section{Introduction}

According to Law Number 23 of 2014 Article 1 Paragraph 6 Regarding Regional Government, regional autonomy is the right, authority and obligation of an autonomous region to regulate and manage its own government affairs according to the interests of the local community in the system of the Unitary State of the Republic of Indonesia. A regional government with autonomy is in a process of transition from a concentrated system to a decentralized system.

Corresponding author. Tel/Mobile Phone: +62 81373607073; E-mail address: putrivialeta@gmail.com 


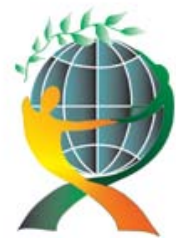

(online) $=$ ISSN $2285-3642$

ISSN-L = $2285-3642$

Journal of Economic Development, Environment and People

Volume 9, Issue 2, 2020

URL: $\underline{\text { http://jedep.spiruharet.ro }}$

e-mail: office jedep@spiruharet.ro

Considering that not all funding sources are viable in the region, the sources of regional revenue must be explored to the fullest. One potential source of revenue is the Regional Original Revenue. According to Law Number 33 of 2004, Regional Original Revenue is aimed at the regional governments by giving them the freedom to finance their regional administration. This is adjusted according to the potential of each region which is an embodiment of decentralization. In terms of improving the services provided to the community, it is necessary to optimally play the role of the government when managing the region. The government has the right to collect taxes to finance the needs of regional autonomy. The role of tax is also often used as a policy instrument by local governments.

The tax that dominates a country's revenue is the Motorized Vehicle Tax. This is because the number of vehicles continues to increase every year, both two-wheeled vehicles (R2) and four-wheeled vehicles (R4). However, the income that has a significant tax value is the Motor Vehicle Tax which is imposed on fourwheeled vehicles. The development of new vehicle units sold in Palembang in 2017 can be divided into two wheels (R2) and four wheels (R4) respectively, which can be seen in Figure 1.

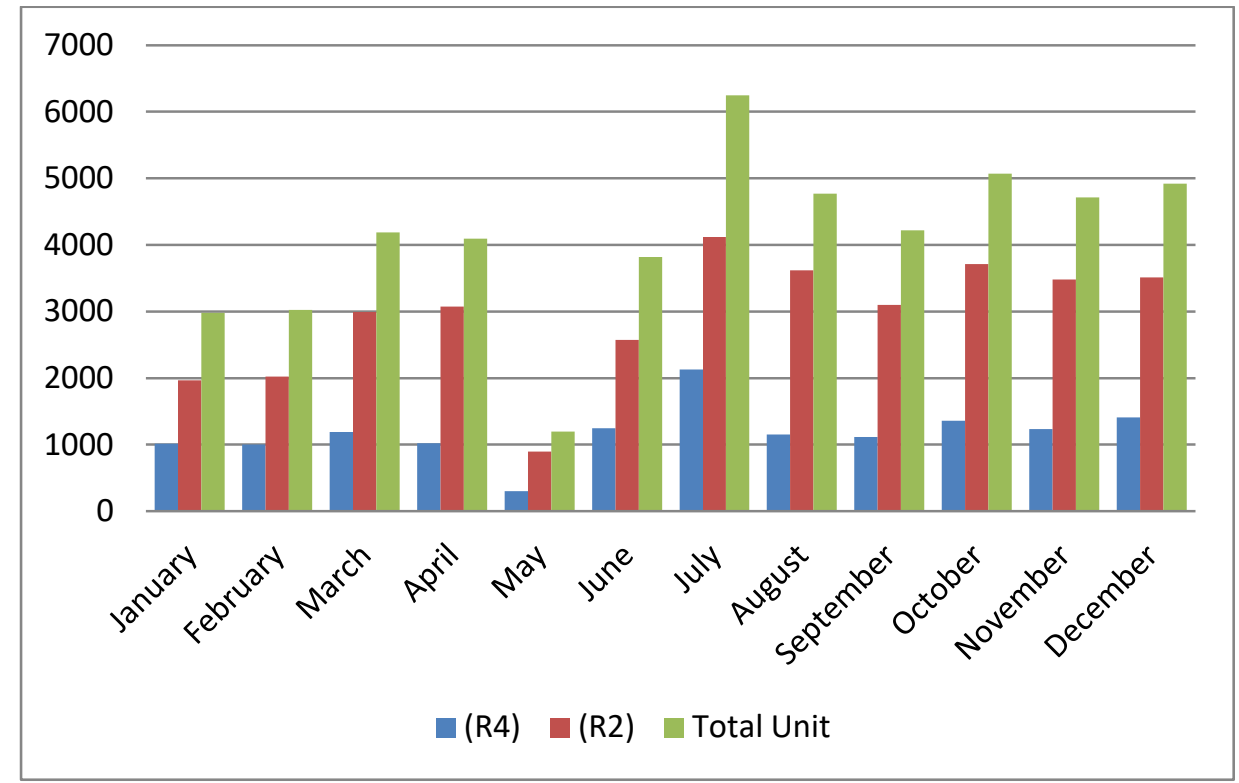

Source: UPT Regional Revenue Agency of Palembang City I, 2018

Figure 1. Chart of New Vehicle Units Sold In Palembang City in 2017

The potential for an increase in the number of motorized vehicles in circulation has made the government renew the regional laws and regulations. The regional government issued South Sumatra Governor Regulation Number 31 of 2016 concerning Regional Taxes. The provisions of article 2 are outlined in paragraphs (1), (3) and (7) regarding the fact that second private motor vehicle ownership and so on is subject to progressive tariffs. The implementation of a progressive tax on motor vehicles is a step taken by the government to reduce the level of congestion and to curb the administration associated with the ownership of motorized vehicles 


\author{
(online) $=$ ISSN $2285-3642$ \\ ISSN-L = 2285 - 3642 \\ Journal of Economic Development, Environment and People \\ Volume 9, Issue 2, 2020 \\ URL: $\underline{\text { http://jedep.spiruharet.ro }}$ \\ e-mail: office jedep@spiruharet.ro
}

owned. If a taxpayer has a private four-wheeled vehicle at the same address, then a greater amount of tax must be paid by the taxpayer.

This phenomenon of progressive taxation has received various responses from the public. One response that can be seen among the public towards the implementation of this progressive tax concerns people's interest in buying new vehicles, especially private cars. This is because progressive taxes will be levied on fourwheeled motor vehicles such as sedans, jeeps, and minibusses.

Based on the problems previously explained, the researcher intends to analyze the effect of progressive tax, the number of vehicles, and tax arrears on the revenue transfer fee of motorized vehicles in the Regional Revenue Agency of South Sumatra Province.

\title{
2. Formulation of the Problem
}

To analyze the magnitude of the influence of progressive tax, the number of vehicles, and tax arrears on the revenue transfer fees of motorized vehicles in South Sumatra Province.

\section{Theoretical and Literature Review}

Taxation plays a significant role in the economic development of every nation through the financing of social and infrastructural projects. It also helps in the distribution of resources, the sharing of revenue, and correcting negative externalities such as the protection of the domestic industry by limiting imports. The provision of public services and the infrastructure funded by tax revenues is a key factor for economic growth and development. Many developing countries are not able to generate the tax revenue needed for national development (Fuest and Riedel, 2009; Adamopoulos, 2010). A moving nation with scarce financial resources is similar to the use of a car with little oil. Taxes are the lifeblood of any economy; if there are no taxes, no nation exists (Ankrah, 2014).

Peacock and Wiseman state that their theory is based on the idea that the government is increasing its spending every year. This causes the government to raise taxes. The public will understand if there is an increase in taxes due to meeting government spending, so the community realizes that the government needs the funds to finance government activities. There is often some level of community willingness to pay taxes. This level of tax tolerance is an obstacle for the government to raise tax collection arbitrarily (Mangkoesoebroto, 1993).

Motorized Vehicle Tax, according to Law Number 3 of 2011, is a tax on the ownership and/or control of motorized vehicles. 'Motorized vehicles' is used to refer to all wheeled vehicles used on all types of road. They are driven by technical equipment in the form of motorcycles and other equipment that functions to convert certain energy resources into the power behind the relevant motorized vehicles including heavy equipment and tool-large equipment that, in its operations, uses wheels and motors that are operated in water.

Referring to the Governor of South Sumatra Province Number 31 of 2016 concerning Regional Taxes, the provisions of article 2, namely the ownership of a second private motor vehicle and so on, are subject to progressive tariffs. This is related to sedans, jeeps, minibusses, station wagons, microbuses, buses, and the like (private vehicles) at the same address.

According to the Regional Regulation of the Province of South Sumatra Number 3 of 2011, BBN-KB is a tax that is imposed on the change of motorized vehicle owner due to buying and selling transactions, auctions, 


\author{
(online) $=$ ISSN $2285-3642$ \\ ISSN-L = 2285 - 3642 \\ Journal of Economic Development, Environment and People \\ Volume 9, Issue 2, 2020 \\ URL: http://jedep.spiruharet.ro \\ e-mail: office jedep@spiruharet.ro
}

inheritance or grants from other parties and income into business entities. The BBN-KB tax subjects are individuals, agencies, or government agencies that can accept the delivery of motorized vehicles.

According to Law Number 11 the Year 2016, tax arrears refers to the principal amount that has not been paid based on a tax bill in which there is a tax principal owed, an underpaid tax assessment letter, an underpaid tax assessment letter, an additional letter of correction, a letter of objection, a decision-based appeal and reconsideration decisions. This causes the amount of tax accrued to increase including taxes that should not be returned as required by law.

In the study by Gnap and Konecny (2015), the variables used were Motorized Vehicle Tax and Fiscal Decentralization. The research period was 2005 - 2013 in the Slovak Republic. The purpose of this research was to identify the Motor Vehicle Tax rates and the changes in the tax revenue in addition to proposing new tax rates that are cheaper and more environmentally-friendly in the governments of each region. The results of the study indicate gradual changes in the Motor Vehicle Tax's impact on the fiscal decentralization policies in the Slovak Republic.

Hennessy and Tol (2010) used the variables of Motor Vehicle Tax and New Car Purchase using the demographic model of car stock. Their results indicate that the impact on tax revenue is large because car owners switch to lower Motorized Vehicle tax rates. The burden of Motor Vehicle Tax has shifted from car ownership to car use, and the overall Motor Vehicle Tax burden on private car transportation has decreased.

Preece (2016) examined automotive taxation in the era of the ASEAN Economic Community (AEC) in 2015. Various policy areas were identified where coordination between the ASEAN members will strengthen the region's position to allow it to become a leading global car manufacturer. In addition to examining the type of vehicle, the level of $\mathrm{CO} 2$ emissions and fuel efficiency as examples of the types of excise taxes applied in the European Union (EU), South Africa, Cyprus, and Thailand are used to highlight areas that can be overcome, leading to a series of reforms that will increase the number of opportunities to achieve this global role. In conclusion, this journal brings together the policy issues discussed and provides a standard structure for car excises and tax that can be considered by the policymakers.

Konecny et al (2016) discussed the impact of fiscal decentralization on Motor Vehicle Tax. This research was conducted in the Slovak Republic. Radically, from time to time, the transfer of competence when setting the tax rates for motorized vehicles in self-governing regions and the use of income through taxes can realistically be used to assess its development and impact. The aim is to eliminate the differences in motor vehicle tax burden between countries and to maintain the current level of tax revenue in self-government. Hartanto, Satria, and Sugiharti (2019) discussed the impact of the Motor Vehicle Tax award on the increase in West Java province's locally-generated revenue. Tax awards are expected to be able to trigger the West Java people to pay their motor vehicle tax. However, there was still an increase in the number of non-re-registered vehicles. Therefore the regulation of the tax award needs to be reviewed. This study aims to find a solution so then the award can increase the West Java province's locally-generated revenue and optimize the collection of the motor vehicle tax. The study concludes that the tax award due to motorized vehicle tax is correlated directly with the increase in locally-generated revenue.

Rismayanti et al (2017) discussed the determinants of the Taxpayer Compliance Test in relation to paying the Motor Vehicle Tax. As one component of provincial taxes, motor vehicle taxes contribute significantly to the local revenue. By properly increasing the number of vehicles, the chances related to the reception area of the motor vehicle tax sector are also increased. This study aimed to obtain evidence regarding the factors that affect taxpayer compliance in terms of paying tax on motor vehicles. The independent variables include 


\author{
(online) $=$ ISSN $2285-3642$ \\ ISSN-L = 2285 - 3642 \\ Journal of Economic Development, Environment and People \\ Volume 9, Issue 2, 2020 \\ URL: $\underline{\text { http://jedep.spiruharet.ro }}$ \\ e-mail: office jedep@spiruharet.ro
}

the socialization of taxation, the knowledge of taxation, income taxpayers, service tax authorities, and tax sanctions. The dependent variable is taxpayer compliance. The population includes taxpayer motor vehicles registered on SAMSAT Mataram. The samples were taken using the incidental method of non-probability sampling. The sample size was calculated using the Slovin formula, which produced 100 respondents. The data were analyzed using multiple linear regression. The results showed that simultaneously, the socialization of taxation, the knowledge of taxation, income taxpayers, service tax authorities, tax sanctions and the interaction between the knowledge of taxation and socialization of taxation has a significantly effect on motor vehicle tax compliance. Next, the partial knowledge of taxation, service tax authorities and tax sanctions has a positive and significant effect on taxpayer compliance. The socialization of taxation and income taxpayers do not have a significantly positive effect on taxpayer compliance.

Raharjo, Pambudi and Bieattant (2018) discussed the influence of the taxpayer's formal knowledge and tax awareness against compliance with paying the motor vehicle tax. The purpose of this study is to determine the effect of the formal knowledge of the taxpayers and the level of taxpayer awareness on the compliance of the motor vehicle taxpayers in the company SAMSAT POLDA in South Jakarta. The data used was primary data, collected by distributing questionnaires to the motor vehicle taxpayers registered in the office of the South Jakarta Police, SAMSAT. The population that was the object of the research was all motor vehicle taxpayers registered in the office of SAMSAT POLDA in South Jakarta up until December 2016. The sampling technique used was accidental sampling. This research used the linear regression analysis method. The results show that the formal knowledge of the taxpayers has a significant positive effect on the compliance of the motor vehicle taxpayers. The results of this study conclude that together, the formal knowledge of taxpayers and the awareness of the taxpayers significantly affect the compliance of the motor vehicle taxpayers.

\title{
4. Methodology and Data
}

The type of data used in this study was secondary data obtained from 16 UPT Regional Revenue Agencies in South Sumatra Province which consisted of monthly data from 2017 to 2018 . The data used was panel data, which is a combination of time series and cross-sections.

There are three fundamental approaches used to estimate the regression model when using panel data, namely a) Pooled Least Square (Common Effect) Model, b) the Fixed Effect Approach Model and c) the Random Effect Approach Model. Because there was one equation used in this study, the authors used the Ordinary Least Squared (OLS) method.

The panel data regression equation used in this model is:

Where:

$$
\mathrm{BBNKB}_{i t}=\alpha+\beta_{1} \operatorname{Tprog}_{i t}+\beta_{2} \mathrm{NKB}_{i t}+\beta_{3} \mathrm{TKB}_{i t}+\mathrm{e}_{\mathrm{it}}
$$

BBNKB $_{i t}=$ Transfer Fees for motorized vehicles

(Rupiah)

Tprog $_{i t}=$ Progressive Tax (Rupiah)

$\mathrm{NKB}_{\text {it }} \quad=$ Number of Vehicles (Unit)

$\mathrm{TKB}_{i t} \quad=$ Motor Vehicle Arrears (Rupiah)

$\propto \quad=$ Constant

$\beta_{1}, \beta_{2} \quad=$ Regression coefficient

$\mathrm{e}_{\mathrm{it}} \quad=$ error term 


\author{
(online) $=$ ISSN $2285-3642$ \\ ISSN-L = $2285-3642$ \\ Journal of Economic Development, Environment and People \\ Volume 9, Issue 2, 2020 \\ URL: $\underline{\text { http://jedep.spiruharet.ro }}$ \\ e-mail: office jedep@spiruharet.ro
}

\title{
Hypotheses
}

1. Progressive tax has a positive effect on the revenue transfer fee of motorized vehicles in South Sumatra Province.

2. The number of vehicles has a positive effect on the receipt of transfer fees for motorized vehicles in South Sumatra Province.

3. Motor vehicle tax arrears have a negative effect on the revenue transfer fee of motorized vehicles in South Sumatra Province.

\section{Empirical Results}

To choose the most appropriate model, several tests were done.

\subsection{Chow Test}

The selection of models between common effects and fixed effects can be done by testing the Likelihood Test Ratio with the provision that if the resulting probability value is significant at alpha $(\alpha) 5 \%$, then a decision can be made using the fixed effect model. Tests were carried out using either the Chow Test or the Likelihood Ratio Test:

H0: Model follows Pool.

H1: Model follows Fixed.

Table - Chow Test Results

\begin{tabular}{lrrr}
\hline Effects Test & Statistic & d.f. & Prob. \\
\hline \hline Cross-section F & 9.473540 & $(15,285)$ & 0.0000 \\
Cross-section Chi-square & 122.979023 & 15 & 0.0000 \\
\hline \hline
\end{tabular}

Source: Secondary data, processed with Eviews 8

Based on the test results, the Chi-square cross-section probability value is 0.0000 where $0.0000<\alpha=5 \%$. Therefore $\mathrm{HO}$ is rejected and $\mathrm{H} 1$ is accepted. The chosen model uses a fixed effect.

\subsection{Hausman Test}

When deciding to use fixed effects or random effects, this can be determined using the Hausman test with the provision that if the probability produced is significant according to its alpha $(\alpha)$ value, then the fixed-effect method can be used. Two tests use the Hausman test:

HO: Model follows the Random Effect

H1: Model follows the Fixed Effect 


\author{
(online) $=$ ISSN $2285-3642$ \\ ISSN-L = 2285 - 3642 \\ Journal of Economic Development, Environment and People \\ Volume 9, Issue 2, 2020 \\ URL: $\underline{\text { http://jedep.spiruharet.ro }}$ \\ e-mail: office jedep@spiruharet.ro
}

The Hausman test in this study was conducted using Eviews 8. The test results can be seen in the following table.

Table - Hausman Test Results

\begin{tabular}{lrrr}
\hline \hline Test Summary & $\begin{array}{r}\text { Chi-Sq. } \\
\text { Statistic }\end{array}$ & Chi-Sq. d.f. & Prob. \\
\hline \hline Cross-section random & 109.523837 & 3 & 0.0000 \\
\hline \hline
\end{tabular}

Source: Secondary data, processed with Eviews 8

In the Hausman Test, the random cross-section probability is 0,000 which is smaller than the significance level of $\alpha=5 \%$. Therefore $\mathrm{HO}$ is rejected and $\mathrm{H} 1$ is accepted. Therefore the best model that can be used in decisionmaking for the model estimation is the fixed effect method.

In line with Nachrowi's research, the selection of the fixed effect method and the random effect method can be made with consideration of the objectives of the analysis. There is a possibility that the data used as the basis for modeling can only be processed by one method due to the various mathematical and technical problems that underlie the calculation. Also, according to some econometrics experts, it is said that if the panel data owned has an amount of time ( $t$ ) that is greater than the number of individuals (i), then it is recommended to use the Fixed Effect method.

Table - Regression Estimation Results of the Fixed Effect method

\begin{tabular}{|c|c|c|c|c|}
\hline Variable & Coefficient & Std. Error & t-Statistic & Prob. \\
\hline $\mathrm{C}$ & $2.06 \mathrm{E}+09$ & $2.20 \mathrm{E}+08$ & 9.343131 & 0.0000 \\
\hline TPROG? & 7.867310 & 1.465025 & 5.370086 & 0.0000 \\
\hline NKB? & 2426294. & 232269.1 & 10.44605 & 0.0000 \\
\hline TKB? & 0.103374 & 0.110435 & 0.936059 & 0.3500 \\
\hline \multicolumn{5}{|c|}{ Effects Specification } \\
\hline \multicolumn{5}{|c|}{ Cross-section fixed (dummy variables) } \\
\hline R-squared & 0.980422 & \multicolumn{2}{|c|}{ Mean dependent var } & $5.04 \mathrm{E}+09$ \\
\hline Adjusted R-squared & 0.979186 & \multicolumn{2}{|c|}{ S.D. dependent var } & $7.70 E+09$ \\
\hline S.E. of regression & $1.11 \mathrm{E}+09$ & \multicolumn{2}{|c|}{ Akaike info criterion } & 44.55613 \\
\hline Sum squared resid & $3.52 E+20$ & \multicolumn{2}{|c|}{ Schwarz criterion } & 44.78845 \\
\hline Log likelihood & -6753.532 & \multirow{2}{*}{\multicolumn{2}{|c|}{$\begin{array}{l}\text { Hannan-Quinn criter. } \\
\text { Durbin-Watson stat }\end{array}$}} & 44.64906 \\
\hline F-statistic & 792.9031 & & & 2.051080 \\
\hline Prob(F-statistic) & 0.000000 & & & \\
\hline
\end{tabular}

Source: Secondary data, processed with Eviews 8 


\author{
(online) $=$ ISSN $2285-3642$ \\ ISSN-L = 2285 - 3642 \\ Journal of Economic Development, Environment and People \\ Volume 9, Issue 2, 2020 \\ URL: http://jedep.spiruharet.ro \\ e-mail: office jedep@spiruharet.ro
}

\title{
5.3 Estimated Results
}

\section{BBNKB $=2,06+7,867310$ Tprog +2426294 NKB $+0,103374$ TKB}

The results obtained show that progressive taxes, the number of vehicles, and motor vehicle arrears have a significant effect on the receipt of motor vehicle transfer fees in the period 2017-2018. This can be seen from the F-statistic value of 792.9031 that is greater than the $F$ table value of 2.634701 with a significance level of $\alpha$ $=5 \%$. This is supported by the probability value of 0.000000 where the value is significant to alpha $(\alpha) 5 \%$.

According to the results of the regression analysis, the progressive tax variable regression coefficient shows a positive value of 7.867310 . The positive coefficient indicates the positive effect of a progressive tax on the receipt of motorized vehicle transfer fees. This means that if the progressive tax increases by 1 , then the receipt of the transfer of motor vehicle transfer fees will increase by 7.867310 , assuming that the other factors outside of the model are considered to be fixed (ceteris paribus). In line with the results of the $t$ test, it shows that the t-value of the progressive tax is 5.370086. This value is greater than the t-table of 1.967877 ( $t$-count> t-table) at the level of $\alpha=5 \%$ with a probability value of 0.0000 . This means that partially progressive taxes have a significant effect on the receipt of motor vehicle transfer fees.

These results are consistent with Peacock and Wisemen's theory which states that the public will understand if there is an increase in taxes due to meeting government spending. People realize that the government needs funds to finance government activities so they have a degree of community willingness to pay taxes (Mangkoesoebroto, 1993). The public will understand that the tax increase will finance public goods, so the public is aware of paying taxes. This statement is a description of the taxpayers who pay motor vehicle tax in the regency/city of South Sumatra Province where the local government, in this case the Governor of South Sumatra, made a policy of progressive tax enactment contained in Pergub Number 31 of 2016 concerning progressive taxation. People continue to pay taxes.

By implementing a progressive tax policy, it is expected that private motor vehicle ownership can be reduced and the use of public transportation is preferred and encouraged by the community. Indirectly, congestion, which is one of the problems in the province of South Sumatra and especially in the city of Palembang, can be controlled. The implementation of a progressive tax on motor vehicles has an impact on society, both positive and negative. The positive impact arising from the imposition of a progressive tax on motor vehicles is influential when it comes to increasing the local revenue which is useful for financing the routine tasks of the local governments concerning infrastructure development for the welfare of the community. The negative impact is that the people are increasingly burdened because the costs incurred when it comes to paying the motor vehicle taxes are increasing.

The results of this study are consistent with the previous study conducted by Sari et al (2017) in that the existence of the application of progressive taxation received responses from the public that were both positive and negative. Progressive taxation is influenced by the sale of new four-wheeled vehicles, but it is not a factor that dominates the decline in the level of car sales. There is a continued increase in the level of motor vehicle tax revenue. In essence, the application of progressive tariffs on motor vehicle tax is a step taken by the government to reduce the level of congestion and to discipline ownership administration. The more motorized 


\author{
(online) $=$ ISSN $2285-3642$ \\ ISSN-L = 2285 - 3642 \\ Journal of Economic Development, Environment and People \\ Volume 9, Issue 2, 2020 \\ URL: http://jedep.spiruharet.ro \\ e-mail: office jedep@spiruharet.ro
}

vehicles are owned under the same name and identity, the greater the tax that must be paid by the community.

These results are also in line with the research by Nurdin et al (2013). The variables used were Progressive Tax and BBNKB Revenue in the Bandung City Region II Kawuluyaan in 2012. The result was that at a 95\% confidence level, Motor Vehicle Tax revenue affects the customs revenue transfer of motor vehicle names. Here, if the value of the Motor Vehicle Tax revenue increases, then it will be followed by an increase in the motor vehicle transfer fee and vice versa.

For the variable number of motor vehicles, the results obtained indicate that the variable number of motor vehicles has a coefficient of 10.44605 . This means that if the number of motor vehicles has increased by 1 , then the receipt of transfer fees will increase by 10.44605 or $10.45 \%$. A positive coefficient means that the increase in the number of motorized vehicles will be followed by an increase in the receipt of transfer fees in the UPT Regency / City of South Sumatra Province. The results of the t-test show that the variable number of motor vehicles significantly influences the receipt of transfer fees at the UPT Regency / City of South Sumatra Province which was strengthened by the results of the t-statistic probability of 0.0000 significant with an alpha $(\alpha)$ of $5 \%$.

There is a significant influence from the number of motorized vehicles on the receipt of the transfer of Motor Vehicle Title Fees due to their close relationship with one another. The variable number of motor vehicles is related to the level of new vehicle purchases, where each new vehicle purchase will be subject to a New Vehicle Names Transfer Tax (BBNKB I). If the number of new vehicles increases, then the receipt of the New Vehicle Names I Return will also increase. With these results, the amendment to the South Sumatra Province Regional Regulation No. 3 of 2011 to the South Sumatra Province Regional Regulation that states that an increase in BBN-KB I tariff (New Vehicles) in an effort to increase regional income to support the implementation of regional autonomy can be said to be successful.

This reasoning is reinforced by the essence of the justification of buying style theory, namely that tax collection only looks at the positive effect related to the adequacy of the state revenue in terms of financing public expenditure. The good effect is the basis of justice. According to this theory, the implementation of the interests of the taxpayers, both individual, and state, can be regarded as the basis of fair tax collection. This theory emphasizes its teaching based on the second function of tax collection, namely the function of the regulation (Pohan, 2014). The government policy regulating the local regulations that raised the BBN-KB I tariff by $2.5 \%$ from previously not making sales of new vehicles in the province of South Sumatra was reduced. This may have occurred because of the taxpayer's reasons for buying new vehicles due to ease, needs, and desires. Increased public purchasing power and easy vehicle credit facilities have led to an increase in motor vehicle purchases in the province of South Sumatra. With the level of down payments being relatively affordable, the interest rate is considered low and the credit installments are not so large that people want to take on motor vehicle loans. Due to the ease of credit, the purchase of new and used motor vehicles continues to grow.

Inadequate public transportation facilities also affect the number of motor vehicle purchases. With a high level of community activity, adequate public transportation facilities are needed. However, local governments have not been able to provide safe and comfortable public transportation facilities. This means that people prefer to use private vehicles rather than public vehicles, which indirectly increases the number of motor vehicle purchases.

The desire factor is also influential because the production of new vehicles continues to grow and the automotive industry uses new technology and continues to innovate. This makes people interested in owning 


\author{
(online) $=$ ISSN $2285-3642$ \\ ISSN-L = 2285 - 3642 \\ Journal of Economic Development, Environment and People \\ Volume 9, Issue 2, 2020 \\ URL: http://jedep.spiruharet.ro \\ e-mail: office jedep@spiruharet.ro
}

these vehicles, meaning that the vehicle purchase rate will increase. As a result of the increased purchase of new vehicles, the transfer of the Motor Vehicle Title Fee is also increased.

\title{
5.4 Government Policy
}

Motor Vehicle Tax makes a large contribution to the local tax revenue. To maximize the motor vehicle tax revenue, the local government issued a policy exempting motor vehicle tax penalties as stipulated in Governor Regulation number 22 of 2016, which is often called the "tax bleaching policy." The policy of exempting motor vehicle tax penalties is carried out to increase public awareness, especially those included under the vehicle tax who object to paying. This can hopefully revive the tax objects that have been inactive so far and order the administrative data related to vehicle ownership. Besides, this policy was issued because it pursues the target of receiving local revenue from the motor vehicle tax sector.

\section{Conclusion}

Based on the results of the study, it can be concluded that progressive taxes, the number of vehicles, and motor vehicle arrears have a significant effect on the receipt of motor vehicle transfer fees in the period 2017 2018. This can be seen from the F-statistic value of 792.9031 which is greater than the value of the $F$ table that is equal to 2.634701 with a significance level of $\alpha=5 \%$. This is supported by the probability value of 0.000000 where the value is significant to an alpha value of $5 \%$.

\section{References}

[1] Basri, Yuswar Zainul \& Mulyadi Subri, 2003.State Finance and Foreign Debt Policy Analysis.Publisher: PT Raja Grafindo Persada, Jakarta.

[2] David, P. 2012. Principles of Taxation of Road Motor Vehicles and Their Possibilities of Application. Volume LX.

[3] Gnap, Jozef \& Vladimir Konecny. 2015. Motor Vehicle Taxation in The Slovak Republic and Its Impacts in The Context of Fiscal Decentralization. Procedia Economics and Finance 34 (2015)344-351.

[4] Hartanto, Ghani Satria \& Dewi Kania Sugiarti. 2019. The Impact of The Motor Vehicle Tax Award on The Increase of The West Java Province's Locally Generated Revenue. Faculty of Law, Padjadjaran University, Indonesia.

[5] Hennessy, Hugh \& Richard S.J. Tol. 2010. The Impact of Tax Reform on New Car Purchases in Ireland. ESRI Working Paper, No.349.

[6] Konecny, Vladimir dkk. 2016. Impact of Fiscal Decentralization on Motor Vehicle Taxation in The Slovak Republic. Vol 17, No 1, 2016.

[7] Mangkoesoebroto, Guritno. 1993. Public Economic. Third issue. Publisher: BPFE, Yogyakarta.

[8] Mardiasmo. 2009. Taxation. Revised Edition 2009. Publisher Andi, Yogyakarta.

[9] Peraturan Daerah Provinsi Sumatera Selatan Nomor 3 Tahun 2011. Tentang Pajak Daerah.

[10] Peraturan Daerah Provinsi Sumatera Selatan Nomor 9 Tahun 2016. Tentang Perubahanatas Peraturan Daerah Provinsi 


\author{
(online) $=$ ISSN $2285-3642$ \\ ISSN-L = 2285 - 3642 \\ Journal of Economic Development, Environment and People \\ Volume 9, Issue 2, 2020 \\ URL: $\underline{\text { http://jedep.spiruharet.ro }}$ \\ e-mail: office jedep@spiruharet.ro
}

Sumatera Selatan Nomor 3 Tahun 2011.

[11] Peraturan Gubernur Sumatera Selatan Nomor 31 Tahun 2016. Tentang Petunjuk Pelaksanaan Peraturan Daerah Nomor 3 Tahun 2011 tentang Perubahan Keduaatas Peraturan Gubernur Nomor 11 Tahun 2012.

[12] Phang, Sock Yong. 1997. Recent of Development in Siangapore's Motor Vehicle Policies. Journal of Transport Economics and Policy, Vol. 31 No. 2.

[13] Phang, Sock Yong. 1993. Singapore's Motor Vehicle Policy: Review Recent Changes and A Suggested Alternative. Volume 27 Issue 4.

[14] Preece, Rob. 2016. Automotive Excise Taxation: What Reforms Are Needed to Best Utilise The ASEAN Economic Community. Word Customs Journal Vol. 9 No. 1.

[15] Raharjo, Tyas Pambudi\& Licke Bieattant. 2018. Influence of Taxpayer Formal Knowledge and Tax Awareness Against Compliance of Tax Motor Vehicles. Proceeding International Seminar on Accounting study program, faculty of Economy Universitas Pamulang, Indonesia.

[16] Rismayanti, Neniet al. 2017 Determinants of Taxpayer Compliance Test in Paying Motor Vehicle Tax. International Conference and Call for Papers, jember.

[17] Sari, Komang Yunita et al. 2017. Impact Analysis of the Application of Progressive Tax on Four-Wheeled Motor Vehicles on New Car Sales in the District of Buleleng.

[18] Sugiyono. 2007. Business Research Method. Publisher: Alfabeta, Bandung.

[19] Surjanti, Rr. Lulus Prapti N.S, et al. 2018. Motor Vehicle Tax Compliance Levels: An Empirical Study and The Determining Factors. Economics \& Business Solutions Journal Volume 2, Number 2, 21-31.

[20] Widjaja, H.A.W. 2007. Regional autonomy and Autonomy Regional Issue 1. Publisher: PT Raja Grafindo Persada, Jakarta.

[21] Yani, Ahmad. 2008. Hubungan Keuanganantara Pemerintah Pusatdan Daerah di Indonesia. Edisi Revisi. Penerbit: Rajagrafindo Persada, Jakarta.

[22] Zongwei, Liu dkk. 2017. Overview of China's Automotive Tax Scheme Current Situation, Potential Problems and Future Direction. Journal of Southeast Asian Research Vol. 2017. 